\title{
Models for the pedagogical integration of information and communication technologies: a literature review
}

\author{
Olga González Sosa ${ }^{a}$ \\ Cristina Hennig Manzuoli ${ }^{b}$
}

\begin{abstract}
Education was, is and will continue to be a field full of questions: Why to teach? What to teach? How to teach? What, how and when to evaluate? Moreover, while the same questions persist, answers to them do not. They are dynamic, and they are transformed according to the demands of the family, the company and government policies. To address these considerations, this article aims to present the results of research into the literature of the last two decades on the elements that characterize a pedagogical model and that have been taken into account in explorations with regard to the educational integration of information and communication technologies and to identify gaps for future research. The results show that only $11 \%$ of the literature reviewed addresses the four questions listed above and concludes on the need to deepen the factors that affect the success of the changes that are introduced in the school, which seek to generate processes of educational transformation, from a holistic perspective.
\end{abstract}

Keywords: Teaching. Educational models. Pedagogical trends. Curriculum. Evaluation.

\section{Introduction}

It cannot be denied that the education system of the 21 st century requires profound changes to respond to society's needs, particularly those related to social and economic changes. Therefore, new "skills and competencies required by the educational standards that each student must be able to achieve

\footnotetext{
a Universidad de La Sabana, Cundinamarca, Colômbia.

b Universidad de La Sabana, Cundinamarca, Colômbia.

Recebido em: 10 mai. 2017

Aceito em: 26 set. 2018
} 
by the end of compulsory education" must be developed (INTERGUAYAMA, 2010, p. 3).

For this reason, leaders in education from international organizations have come together to formulate a global framework enabling countries to face the challenges of the information society. An example of this was the World Summit on the Information Society (Geneva, 2003; Tunis, 2005) convened by the International Telecommunication Union (ITU), which defined goals that can be adapted to the plans and policies of each nation. These goals are meant to guarantee equal opportunities and quality education that responds to the needs of all students, where lifelong learning and diversified teaching of information and communication technology applications in social and economic fields are promoted for improving learning processes and developing student competences (BETANCOURT, 2004; DECLARATION OF INCHEON, 2015; UIT, 2005).

To meet these demands, numerous investigations have been conducted around the world describing experiments with technology integration in specific contexts. Although many studies have reported successful results with regard to the use of technology to improve students' motivation and learning, there seems to be a disconnection in the holistic reflections regarding visions for the type of person to be shaped, the curriculum, the pedagogy, the types of relationships of the actors involved, and the evaluation of learning that characterizes each educational institution. In this regard, Fernandes et al. (2016), highlight the importance of school management to promote the organization, mobilization and articulation of material and human conditions to ensure the effective progress of educational processes.

Some research (BADILLA QUINTANA; MEZA FERNÁNDEZ, 2015) has focused on producing scenarios in which teachers can create learning situations that simulate training experiences for students. These experiences are encompassed in the implementation of virtual environments for collaborative work and social networks where interaction is valued.

Other research has adhered to the Technological Pedagogical and Content Knowledge (TPACK) model to improve performance of teaching and learning processes in specific areas (SAMPAIO, 2016; TAI et al., 2015). These studies report positive results when the model is used mainly for learning organized writing as well as in the absorption of content. Others have focused on investigating the reasons why teachers integrate information and communication technology (ICT) 
into their classes. Results reveal that the use of these technologies is directly proportional to the teacher's mastery of them as well as to resources availability, to how much they motivate students and to the use of constructivist methods in teaching/learning processes (PETKO, 2012).

Teachers' perception of the integration of technologies, the competencies they possess and their relationship are public policies that have also been subject of research. An example is the study carried out by Herrera et al. (2018), who conclude that perceptions and experience of teachers are fundamental factors for the educational integration of ICTs and that there is not necessarily a relationship between their learning and the requirements of the regulations.

Along these same lines of teacher beliefs, the studies report that teachers seldom use multimedia resources like YouTube videos, since they believe that these media are only used for fun and for motivating activities, and do not require much effort by students in terms of processing information (KRAUSKOPF et al., 2012).

Other studies have focused on the use of an electronic portfolio for the development of cognitive skills in b-learning environments. They conclude that the use of these portfolios, together with problem-based learning models, helps develop problem-solving skills and critical thinking, since they allow students to create, synthesise and systematise conclusions (KORANEEKIJ; KHLAISANG, 2015)

In another vein, some researchers have studied the influence of connectivity as a model for training industrial design students, finding positive results related to the creation of learning networks through online courses and other technology tools such as wikis, blogs, and 3D printing, all of which contributed to the absorption of knowledge and student creativity (RENDA; KUYS, 2015). Other studies have focused on collaborative work to create scenarios where future teachers face situations in which they can simulate the decisions required in teaching students.

Finally, although there are initiatives to create models and experiences for training students and teachers that incorporate technology, educational institutions must review and adjust the strategies implemented by first analysing aspects such as the vision for the type of person that they want to shape, the curriculum, the pedagogy, the types of relationship between the actors involved and the evaluation of learning. Results should provide a clear vision for addressing the pedagogical 
strategies that promote lifelong learning: learning to know, learning to do, learning to live together and learning to be.

Therefore, if the integration of technology is indispensable for the 21 st century education, then it is imperative for the pedagogical models of educational institutions to adapt to this need. This article intends to present a bibliographic review of the elements that should be considered in the integration of ICT into education in order to understand how they relate to current pedagogical models and to identify areas for future research.

\section{Review methodology}

The methodology for the literature review was systematic, taking into account the stages illustrated in the Graph 1, adapted from the Okoli and Schabram's (2010) approach.

\subsection{Objective}

The objective of the bibliographic research was to use the learning experiences of students or teachers that involved the pedagogical integration of ICT to identify how these strategies are related to the elements that define a pedagogical model.

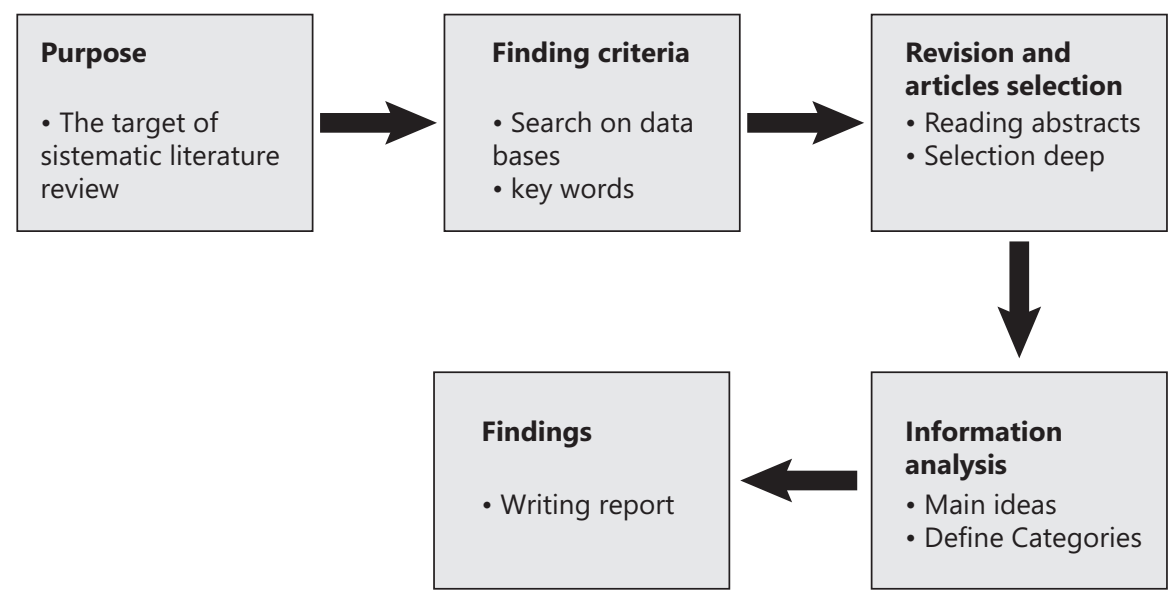

Source: Prepared by the author (2017).

Graph 1. Review method 


\subsection{Initial search criteria}

Electronic searches were conducted in educational databases such as Scopus, Jstor and ProQuest. In addition, different combinations of keywords were used, such as "ICT integration models", "ICT and teaching", and "ICT and learning". Based on these search criteria, a total of 3,397 high-quality studies published from 1994 through the first quarter of 2017 were found.

To further refine the results, a search filter using keyword combinations was applied. Furthermore, from the resulting 644 publications, only $20 \%$ of the articles were selected as shown in the Table 1.

\subsection{Selection of articles and reading}

Once the potential articles were identified, a preliminary reading was carried out to verify that they met the following criteria:

Table 1. Articles published by year

\begin{tabular}{|c|c|c|c|c|c|c|c|c|c|}
\hline \multirow[b]{2}{*}{ Database } & \multirow[b]{2}{*}{ Keywords } & \multirow{2}{*}{$\begin{array}{l}\text { Articles } \\
\text { meeting } \\
\text { the } \\
\text { criteria }\end{array}$} & \multirow[b]{2}{*}{ Filter } & & \multicolumn{5}{|c|}{ Articles meeting the filter criteria } \\
\hline & & & & & $\begin{array}{c}2017- \\
2012\end{array}$ & $\begin{array}{l}2011- \\
2006\end{array}$ & $\begin{array}{l}2005- \\
2000\end{array}$ & $\begin{array}{c}1999- \\
1994\end{array}$ & TOTAL \\
\hline \multirow[b]{2}{*}{ Scopus } & \multirow{2}{*}{$\begin{array}{c}\text { ICT } \\
\text { Integration } \\
\text { model }\end{array}$} & \multirow[b]{2}{*}{853} & \multirow[b]{2}{*}{$\begin{array}{l}\text { Article/ } \\
\text { Social }\end{array}$} & $\begin{array}{l}\text { Number } \\
\text { published: }\end{array}$ & 142 & 102 & 21 & 3 & 268 \\
\hline & & & & $\begin{array}{l}\text { Number } \\
\text { selected: } \\
20 \%\end{array}$ & 28 & 20 & 4 & 1 & 54 \\
\hline \multirow[b]{2}{*}{ JSTOR } & \multirow{2}{*}{$\begin{array}{c}\text { ICT } \\
\text { Integration } \\
\text { model AND } \\
\text { learning } \\
\text { AND } \\
\text { teaching }\end{array}$} & \multirow[b]{2}{*}{324} & \multirow{2}{*}{$\begin{array}{l}\text { Education: } \\
\text { primary, } \\
\text { middle, } \\
\text { high } \\
\text { ICT }\end{array}$} & $\begin{array}{l}\text { Number } \\
\text { published }\end{array}$ & 45 & 88 & 48 & 4 & 185 \\
\hline & & & & $\begin{array}{l}\text { Number } \\
\text { Selected: } \\
20 \%\end{array}$ & 9 & 18 & 10 & 1 & 37 \\
\hline \multirow{3}{*}{ ProQuest } & \multirow{2}{*}{$\begin{array}{c}\text { ICT } \\
\text { Integration } \\
\text { model AND } \\
\text { learning } \\
\text { AND } \\
\text { teaching }\end{array}$} & \multirow[b]{2}{*}{2,220} & \multirow{2}{*}{$\begin{array}{l}\text { Primary } \\
\text { teaching } \\
\text { methods } \\
\text { innovations } \\
\text { models }\end{array}$} & $\begin{array}{l}\text { Number } \\
\text { published }\end{array}$ & 123 & 60 & 8 & 0 & 191 \\
\hline & & & & $\begin{array}{l}\text { Number } \\
\text { selected: } \\
20 \%\end{array}$ & 25 & 12 & 2 & 0 & 38 \\
\hline & Total & 3,397 & & $\sum 20 \%$ & 62 & 50 & 15 & 1 & 129 \\
\hline
\end{tabular}

Source: Prepared by the author (2017). 
- Studies related to practices that incorporate ICT for teaching or learning

- Studies that consider strategies for incorporating ICT into teaching at any level of education

- Studies including at least one element related to the definition of the pedagogical model

Finally, the first 100 articles that met the selection criteria were chosen. The Graph 2 shows them organized by year:

\subsection{Organization and analysis of the information}

An in-depth reading of the articles focused on identifying how the authors approached the following questions related to the attributes required by a pedagogical model: "Why to teach/learn?", "What to teach/learn?", "How to teach/learn?", "When to teach/learn?", and "What, how and when to evaluate?". In addition, we highlighted the foundational educational models that were used and whether they were linked to a pedagogical theory or not.

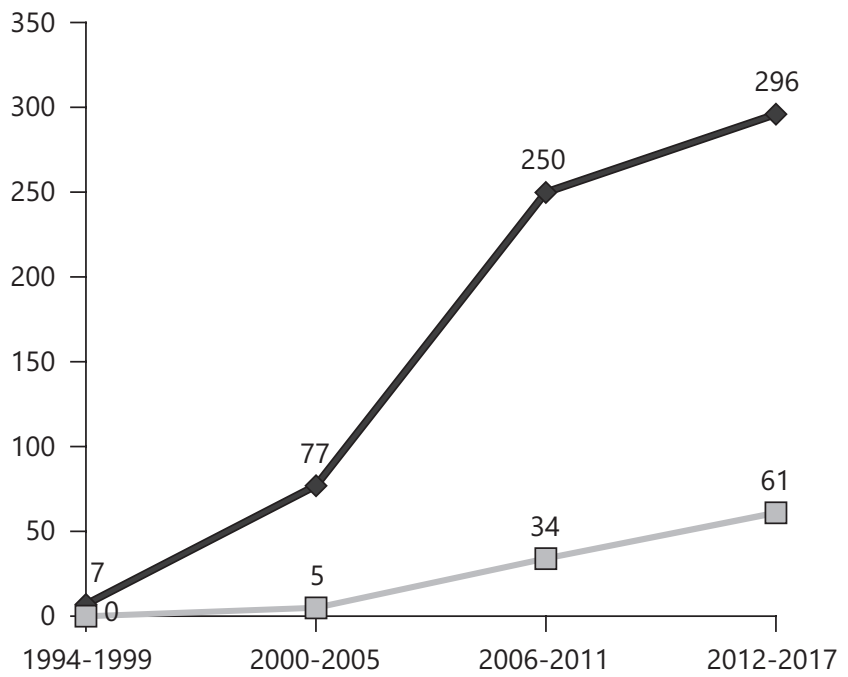

Source: Prepared by the author based on Scopus, ProQuest, Jstor (2017).

Graph 2. Documents publishing and selecting per year 
Data were organized in tables using software programs such as QDA Miner, Excel and SPSS.

\subsection{Reporting of results}

Once the in-depth review of the selected articles was concluded, we drafted the results report and established the relationship between the approaches for incorporating technology into educational practices and the characteristic elements of a pedagogical model.

\section{Results}

All the selected articles describe strategies for incorporating information and communication technologies into teaching or learning. Of these, $57 \%$ report on the results of projects in basic and secondary education and 10\% in higher education, and $33 \%$ correspond to teacher training studies.

The countries of origin of these articles are shown in Graph 3. The country with the largest number of publications in this area is Spain, with $11 \%$ of the total. The United States, the United Kingdom and Malaysia each account for 10\% of the total, followed by Australia with 9\%. Chile, Greece, India, Belgium, Canada and Turkey each represent $4 \%$ of the total, while Portugal and Taiwan each account for $3 \%$. Germany, France, Kenya, Nigeria, and Serbia each constitute $2 \%$ of the

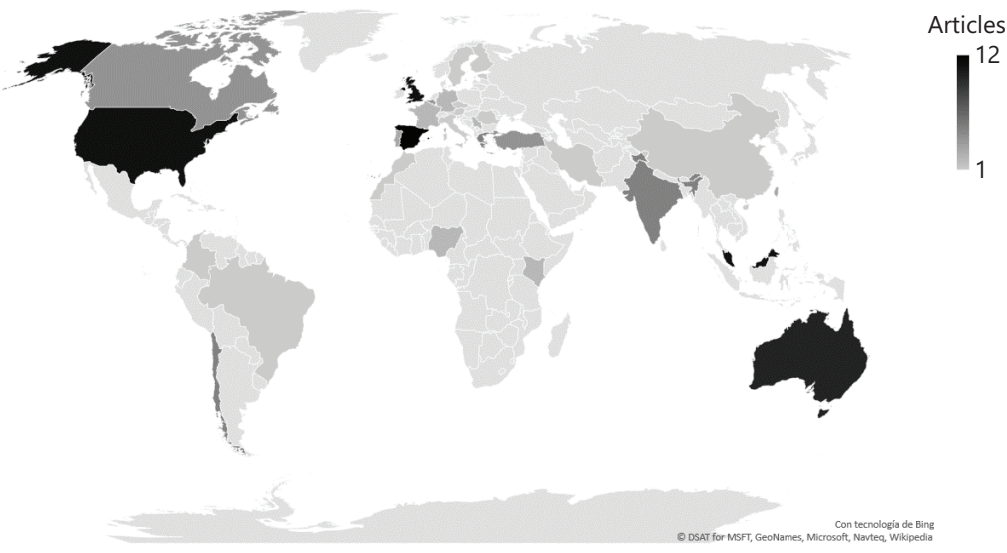

Source: Prepared by the author (2017).

Graph 3. Documents selects country 
total. Other countries accounting for only $1 \%$ each of the total are China, Austria, Brazil, Colombia, Estonia, Finland, Iran, Italy, Morocco, Norway, New Zealand, the Czech Republic, Romania and Sweden.

It is relevant to approach the five questions that define a pedagogical model, illustrated in Graph 4. Of the articles reviewed, it was found that $28 \%$ only address one of the questions, $35 \%$ address two questions, $26 \%$ address three questions, and $11 \%$ address four questions. None of the articles addresses all five questions.

Furthermore, $58 \%$ of the selected articles establish a relationship between the strategy and a foundational educational model, while $25 \%$ associate the study with a theory of learning. Only $17 \%$ of the articles mention both, while $34 \%$ make no mention of either.

\section{Synthesis of the information}

The following is a synthesis of the findings identified in the approaches for incorporating technology into educational practices and possible relationships with a pedagogical model, based on the five questions that define it (COLL, 1991).

\subsection{Educational models for the integration of ICT and}

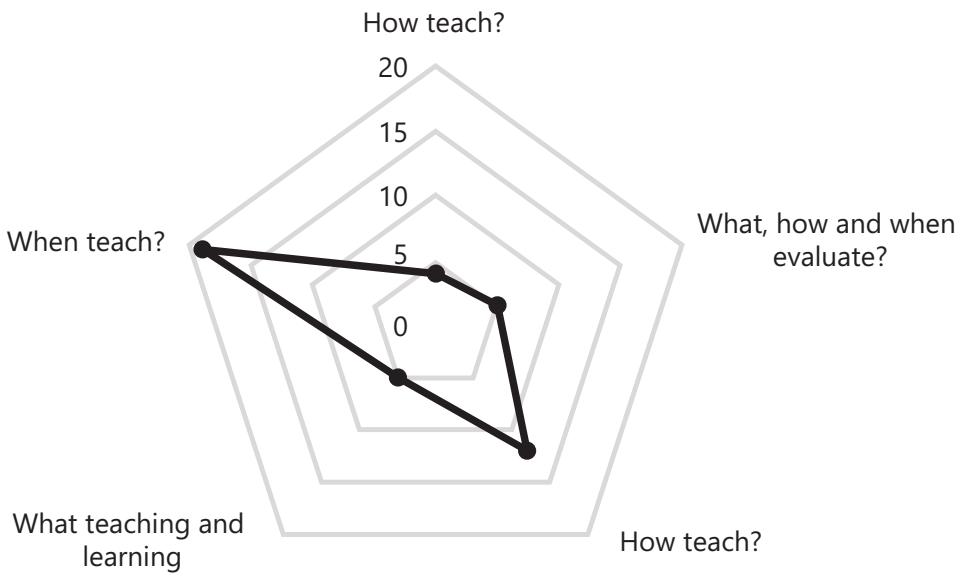

Source: Prepared by the author (2017).

Graph 4. Strategies of ICT integration reported 


\section{related pedagogical theories}

In order to provide a conceptual framework to understand how teachers integrate ICT into teaching and learning processes, $17 \%$ of the studies reviewed use the TPACK model developed by Mishra and Koehler (2006) (some are shown in Table 2). Murthy et al. (2015) and Warriem et al. (2014) build on this knowledge base with the A2I model (Attain-Align-Integrate). Similarly, the teacher's role in process innovation is analysed via the K20 model (WILLIAMS et al., 2008), the Teaching Development Programme model (TDP) (ALBION et al., 2015), the Concerns-Based Adoption Model (CBAM) (KARMESHU et al., 2013; PEARSON, 2015), and the Technology Acceptance model (ALRESHEED et al., 2015). Regarding the study of the dynamic relationships between learning agents and ICT, Toh (2016), Zagami (2013) and Lin (2011) used the ecological model as a reference point.

Additionally, in order to understand the process of adopting educational innovations resulting from the incorporation of ICT, 7\% of authors analyse the relationship between the perceived attributes of the innovations and their rate of adoption by applying the theory of diffusion (Table 2).

Moreover, the design of learning environments founded on strategies that involve technologies is based on instructional design models such as the KOLB model (EBISINE, 2015), the Substitution Augmentation Modification Redefinition (SAMR) model (HAMILTON et al., 2016; NKONKI; NTLABATHI, 2016), and the Learning Cycle model (YILDIZ; KOÇAK, 2016), which enable the active participation of students.

The learning strategies that are gaining strength are based on e-learning models (ALKOUDMANI, 2015; ARIF et al., 2015; DEBANDE, 2004) and the flipped model (KOSTARIS et al., 2017; CHEN; CHANG, 2017; GARCÍA-SÁNCHEZ; JOSE, 2017; KOSTARIS et al., 2017), from which the self-regulated learning

Table 2. Studies based on the TPACK model and on the theory of diffusion

\begin{tabular}{ll}
\hline TPACK model & Theory of diffusion \\
\hline
\end{tabular}

Kabakci; Coklar, 2014; Koh et al., 2013; Koh; Sing, 2011; Chai et al., 2011; Sangra; Gonzalez-Sanmamed, 2010; Jimoyiannis, 2010; Lefebvre, 2014; Hofer; Grandgenett, 2012; Van Laer et al., 2014.

Nyagowa, 2014; Emin-Martinez; Ney, 2013;

Vanderlinde; Johan, 2011; Liu et al., 2010;

Sloep et al., 2006; Niemel; Helevirta, 2017.

Source: Prepared by the author (2017). 
model was born (CARNEIRO, 2006). Additionally, there are references on problem-based learning (ARATI et al., 2011; VIRKUS, 2008), Digital Game Based Learning (DGBL) (COUCEIRO et al., 2013; EMIN-MARTINEZ; NEY, 2013; LOCKLEY; BOYLE, 2014; MANESSIS, 2013;) and object-based education (RAJU et al., 2016).

Finally, the literature reports that theories of learning associated with the aforementioned models are based on the thought of Papert, Piaget and Vygotsky (DREHER et al., 2009). The premise is that the creation of knowledge and the acquisition of skills are active and interrelated processes, hence the relationship of ICT integration strategies with social constructivism. This strategy contribute to the collaborative and student-centred learning (COUCEIRO et al., 2013; GARCÍA-VALCÁRCEL et al., 2013; KOH; SING, 2011; KABICHER et al., 2009; MARTÍN; DE ARRIBA, 2017; MURTHY et al., 2015; PEINADO-MIGUEL et al., 2013; WANG, 2008).

The tendencies for each question about the pedagogical model, found in the literature are shown below:

\subsection{Why to teach?}

The studies reviewed refer to the digital inclusion as a necessary condition for achieving social equity and justice (RANIERI et al., 2009; WILLIAMS et al., 2008). A quality education that is based on key competencies for personal development, social integration and for autonomous creative and innovative work that enables individuals to develop throughout life. (CAMPIÓN et al., 2016; GARCÍA-VALCÁRCEL et al., 2013; KARMESHU et al., 2013; NYAGOWA, 2014; ONWUAGBOKE et al., 2015; PEINADO-MIGUEL et al., 2013; SEGREDO et al., 2017; SILVA et al., 2014; VANDERLINDE; JOHAN, 2011; WILLIAMS et al., 2008).

Additionally, authors as Kabakci e Coklar (2014), Kabicher et al., (2009) e Zhu, 2013 and advocate for teaching ethics to ensure that citizens use technology appropriately and for cultural change to recognize new values, norms and ways of doing things.

\subsection{When to teach?}

The way in which the protagonists in the educational context are related determines when to teach or learn, hence the importance of clarifying the roles of the actors involved in this process. 
In $90 \%$ of the literature reviewed that addresses the role of the teacher, it is stressed that the responsibility for planning or managing learning activities falls on teachers. Therefore, one could say that it is the teacher who decides when to teach or learn. It also points to the student as the centre of the educational process and stresses the need for students to assume active and highly self-directed roles in learning environments involving technology.

Table 3 presents some of the authors that explicitly address the roles of the teacher and the student.

\subsection{What to teach?}

It was found in the literature that content developed in the context of the reported educational experiences was created from two perspectives: global curricula based on standard guidelines and structured by discipline, and flexible curricula

Table 3. Literature that discusses the roles of teacher and student

\begin{tabular}{lc}
$\begin{array}{l}\text { Teacher is in charge of planning and } \\
\text { designing learning activities }\end{array}$ & $\begin{array}{c}\text { Student is at the centre of the educational } \\
\text { process and is responsible for his or her } \\
\text { own learning }\end{array}$ \\
\hline
\end{tabular}

Koh et al., 2013; Tapiska et al., 2016;

Chai et al., 2011; Jimoyiannis, 2010;

Lefebvre, 2014; Lagrange; Erdogan, 2009;

Ham; Cha, 2009; Dani; Koenig, 2008;

Deaney, 2006; Ruthven; Hennessy, 2002;

Sharija; Watters, 2012; Taylor; Duran, 2006;

Nyagowa, 2014; Warriem et al., 2014;

Koh et al., 2013; Raju et al., 2016; Lin, 2011;

Karmeshu et al., 2013; Liu et al., 2016

Ursavas, 2015; Vanderlinde; Johan, 2011

Source: Prepared by the author (2017).

Table 4. Origins of curricular content

\begin{tabular}{|ll|}
\hline \multicolumn{1}{c|}{$\begin{array}{c}\text { Global curricula based on standard } \\
\text { guidelines }\end{array}$} & \multicolumn{1}{c|}{$\begin{array}{c}\text { Flexible curricula: core educational } \\
\text { experiences }\end{array}$} \\
\hline Campbell et al., 2015; Alresheed et al., & $\begin{array}{l}\text { Ranieri et al., 2009: Mobile learning } \\
\text { Deaney et al., 2006: Creation of digital content } \\
\text { 2015; Silva et al., 2014; Arati et al., 2011; }\end{array}$ \\
$\begin{array}{l}\text { Williams et al., 2008: Authentic learning } \\
\text { Chee; Mehrotra, 2012; Hutchison; Reinking, }\end{array}$ & $\begin{array}{l}\text { Smith et al., 2009: Project-based assignments } \\
\text { Pohl et al., 2008: E-learning from ECODESIGN }\end{array}$ \\
2011; Ham; Cha, 2009; De et al., 2011; & $\begin{array}{l}\text { Suárez-Guerrero et al., 2016: Use of tablets } \\
\text { Zagami, 2013; Vanderlinde; Johan, 2011 }\end{array}$ \\
\end{tabular}

Source: Prepared by the author (2017). 
based on core educational experiences and supported by mobile learning, digital content, the promotion of authentic learning and project-based assignments, among others. Some examples are presented in Table 4.

Regarding curriculum design, Ham and Cha (2009) note that the categories used to define curricula are quite similar among different countries and stable over time, despite local idiosyncrasies such as economic conditions and socio-historical characteristics. Under these conditions, it is expected that a well-planned curriculum will lead to the comprehensive development of the student (EBISINE, 2015). An example of this is the spiral curriculum, characterized by an iterative process of content review (MURTHY et al., 2015; WARRIEM et al., 2014).

Nevertheless, there are those who advocate for a flexible curriculum that is adaptable to the interests of students (JIMÉNEZ et al., 2008; KABICHER et al., 2009; PEARSON, 2015; WILLIAMS et al., 2008). Thus promoting a vision that is not limited to the simple acquisition of basic knowledge (writing, reading, arithmetic, art, etc.), but also promotes learning experiences aimed at social skill development, problem solving, good work habits (self-sufficiency, responsibility, organization) and the capacity for reflection, critical thinking and initiative (EMIN-MARTINEZ; NEY, 2013; GARCÍA-VALCÁRCEL et al., 2013; SEGREDO et al., 2017).

\subsection{How to teach?}

Didactics is one of the concerns of teachers, tutors and in general of the people in charge of teaching processes, who are constantly searching for strategies to harmonize teaching practices with the needs of society and the historical characteristics of the times. For this reason, it is not surprising that, in the last decade, research in education has focused on identifying new ways of teaching that go beyond the mere transmission of knowledge to reach a state where the generation of knowledge, supported by information and communication technologies, is valued.

In the research reviewed that explicitly addresses some type of teaching and learning strategy, $30 \%$ of the authors value collaborative work and emphasize the value of specific competencies in technology for sharing resources and learning cooperatively (SHARIJA; WATTERS, 2012; TAYLOR; DURAN, 2006; ; WARRIEM et al., 2014; WILLIAMS et al., 2008; ZHU, 2013; ZYAD, 2016). They also encourage self-direction and lifelong learning 
(DREHER et al., 2009; MARTÍN; DE ARRIBA, 2017; POHL et al., 2008; et al., 2017; WEBB, 2006 ).

Furthermore, the use of ICT facilitates the redesign and combination of traditional materials with innovative multimedia resources (AREA-MOREIRA et al., 2016; KOH; SING, 2011; ONWUAGBOKE et al., 2015; SAXENA, 2017; THUNE; WELLE-STRAND, 2005) that can stimulate the development of skills such as critical thinking, problem-solving, communication and creativity (LIN, 2012; YUNUS, 2007; MARCOUX; LOERTSCHER, 2009; NIEMEL; HELEVIRTA, 2017). In addition, ICT presents options for serving students with special learning needs (McINERNEY, 2005).

\subsection{What, how and when to evaluate?}

The evaluation of learning is a major challenge for educational transformation in the 21 st century. It is not enough to issue a quantitative value or a judgment at the end of a course. The function of an evaluation is to provide information at every moment in the teaching process. As discussed by Karmeshu et al. (2013), evaluation is a continuous event rather than a discrete one. It includes evaluation of learning at the beginning and at the end of the instruction (summative) as well as during the process (formative).

In this sense, the teacher's dialogue with the student regarding the learning evaluation (the shared evaluation) favours objective assessment and decisionmaking (ROMERO-MARTÍN et al., 2017). On the other hand, group selfevaluation is essential for a team to analyse its progress and errors as well as to identify the elements that must be changed to improve its collective performance (PEINADO et al., 2013).

Murthy et al. (2015) show how teachers manage to devise student-centred learning strategies but note some difficulties in aligning evaluation strategies. In this regard, Warien et al., $(2014$, p. 886$)$ notes that the main idea of the model of "constructive alignment is achieved when the activities of learning, teaching and evaluation align with the expected results of student learning".

Other studies reviewed show how technology facilitates feedback processes and the development of strategies to advance students' capabilities through the systematization of information (DANI; KOENIG, 2008; DEANEY et al., 2006; LAGRANGE; ERDOGAN, 2009), educational games and evaluation rubrics. 
The gamification methodology provides immediate feedback to students, allowing them to test hypotheses and learn from their actions (COUCEIRO et al., 2013), while rubrics establish criteria and standards by levels by providing scales that enable educators to determine the quality of student performance in specific tasks (VERA VÉLEZ, 2008).

Finally, Franklin and Smith (2015) identified the following key principles for the effective use of rubrics for performance evaluation: (1) clarify the assessment task; (2) enable regulation of planning of assignments; (3) produce work of better quality; (4) increase student confidence in undertaking the assessment task; (5) provide clear descriptions at each level of performance; (6) provide explicit learning outcomes; and (7) make grading fair and transparent.

\section{Conclusions}

Education and educational policies are linked to economic growth and the demands of society, and although changes happen slowly, in recent decades, the development of information and communication technologies has led the academic community to seek to transform schools and teaching strategies. Evidence of this can be found in the exponential growth in research studies related to the pedagogical integration of ICT.

The research design that dominates the literature reviewed in this study are case studies that further the understanding of the methodologies and strategies applied by some institutions to integrate technology into the educational process This phenomenon results in strategies that were successful during implementation, but in few cases are sustainable over time.

It is important that the studies carried out on this subject, in addition to holistically considering all sectors and educational actors, be accompanied by a reflection based on the classical theories of learning and emerging theories of learning in the digital era. This allows to deepen the understanding of the factors that affect the success of the changes that are introduced in the school that seek to generate processes of educational transformation. In this regard, models such as TPACK, A2I, K20, and TDP, among others, give theoretical elements to the pedagogical integration of ICT and contribute in the consolidation of the transformation of education. Similarly, a number of alternative teaching strategies for stimulating innovation are beginning to gain momentum: e-learning, the flipped model, problem-based learning aided by technology, and game-based learning. 
A concurrence in the aims of education was discovered in the literature review, concerning the training of independent, creative and innovative citizens to enable them to continue developing throughout life. However, only some studies refer to education about values and to the development of ethical citizens; skills necessary to achieve an integral formation of students, so that they perform with sensitivity and capacity for critical reflection and understanding of the globalized world and adapt quickly to changes.

Regarding the teacher's function, it continues to play a leading role in the process. Although the literature points to the student as the centre of the educational process, it is the teacher who decides what to teach, plans and designs the learning environments. To achieve a student-centred approach, a high level of student participation in the learning process is required, which implies that the teacher would have "low control". The teacher's role is therefore reduced to encouraging students to take the initiative to plan and complete learning activities. With a teacher-centred approach, the teacher prefers to assume responsibility for student performance by modelling learning activities and exemplifying a "high control" teaching behaviour (den Brok et al., 2004, referenced by Kale; Goh, 2014).

Regarding evaluation, the conclusions of studies that address this topic concur in favouring a formative, shared evaluation oriented towards improving learning and not only towards performance measurement of content domain. This is achieved through a process of verification, assessment and decision-making in order to optimize the teaching/learning process (Romero-Martín et al., 2017). In this process, ICT is a tool that allows the processing of large volumes of information from rubrics or portfolios and thus offers an immediate and timely feedback that allows clear information on the progress of students.

Finally, it is necessary to delve deeper into student-centred curricula, the evaluation of learning, learning assessment strategies, how to achieve education that is truly centred on the student, and the harmonization of emerging methodologies with traditional pedagogical approaches using current pedagogical principles. It is also important to investigate the mechanisms of participation of all educational actors in the formulation of strategies that allow changes to be made in order to achieve the training objectives.

\section{Declarations}

\subsection{Availability of data and materials}

Not to be shared. The main articles reviewed have been shown in the article. 


\subsection{Competing interests}

Not applicable

\subsection{Funding}

This research is funded by Universidad de La Sabana

\subsection{Authors' contributions}

Both authors contributed equally

\subsection{Acknowledgements}

Not applicable

\subsection{Authors' information}

The authors are members of a research group interested in teacher training in ICT and have studies in this area. 


\section{Modelos para a integração pedagógica de tecnologias de informação e comunicação: uma revisão da literatura.}

\section{Resumo}

A educação foi, é e continuará a ser um campo cheio de questões: por que ensinar? $O$ que ensinar? Como ensinar? O que, como e quando avaliar? Além disso, enquanto as mesmas questões persistem, as respostas a elas não. São dinâmicas e se transformam de acordo com as demandas da família, da empresa e das políticas governamentais. Para abordar estas considerações, este artigo tem como objetivo apresentar os resultados da pesquisa na literatura das últimas duas décadas sobre os elementos que caracterizam um modelo pedagógico e que foram levados em conta nas explorações sobre a integração educacional das tecnologias de informação e comunicação e identificar lacunas para pesquisas futuras. Os resultados mostram que apenas $11 \%$ da literatura consultada aborda as quatro questões listadas acima e conclui sobre a necessidade de aprofundar os fatores que afetam o sucesso das mudanças que são introduzidas na escola, que buscam gerar processos de transformação educacional, desde uma perspectiva holística

Palavras-chave: Ensino. Modelos educativos. Tendências pedagógicas. Currículo. Avaliação.

\section{Modelos para la integración pedagógica de las tecnologías de la información y la comunicación: una revisión de la literatura}

\section{Resumen}

La educación era, es y seguirá siendo un campo lleno de preguntas: ¿por qué enseñar? ¿Qué enseñar? ¿Cómo enseñar? ¿Qué, cómo y cuándo evaluar? Además, si bien las mismas preguntas persisten, las respuestas a ellas no. Son dinámicos y se transforman de acuerdo con las demandas de la familia, la empresa y las políticas del gobierno. Para abordar estas consideraciones, este articulo tiene como objetivo presentar los resultados de la investigación en la literatura de las últimas dos décadas sobre los elementos que caracterizan un modelo pedagógico y que se han tenido en cuenta en las exploraciones con respecto a la integración educativa de las tecnologías de información y comunicación e identificar las lagunas para futuras investigaciones. Los resultados muestran que solo el $11 \%$ de la literatura consultada aborda las cuatro preguntas enumeradas anteriormente. $y$ se concluye sobre la necesidad de profundizar en los factores que inciden en el éxito de los cambios que se introducen en la escuela, que buscan generar procesos de transformación educativa, desde una perspectiva holística.

Palabras clave: Docencia. Modelos educativos. Tendencias pedagógicas. Currículo. Evaluación. 


\section{References}

ALBION, P. R. et al.Teachers' professional development for ICT integration: Towards a reciprocal relationship between research and practice. Education and Information Technologies, v. 20, n. 4, p. 655-73, Dec. 2015. https://doi.org/10.1007/s10639-015-9401-9

ALKOUDMANI, R. M. Challenges to web-based learning in pharmacy education in arabic language speaking countries. Archives of Pharmacy Practice, v. 6, n. 3, p. 41-47, Jul. 2015.

ALRESHEED, S.; LEASK, M.; RAIKER, A. Integrating computerassisted language learning in saudi schools: a change model. Turkish Online Journal of Educational Technology, v. 14, n. 4, p. 69-77, 2015. https://doi.org/10.1007/978-3-319-33808-8_22

ARATI, D.; TODOROVA, A.; MERRETT, R. Implementation and sustainability of a global ICT company's programme to help teachers integrate technology into learning and teaching in germany, france and the UK. ALT-J: Research in Learning Technology, v. 19, suppl. 1, p. 170-81, 2011. https://doi.org/10.3402/rlt.v19s1/7802

AREA-MOREIRA; M., HERNÁNDEZ-RIVERO, V.; SOSA-ALONSO, J. Modelos de integración didáctica de las TIC en el aula. Comunicar, v. 24, n. 47, p. 79-87, Apr. 2016. https://doi.org/10.3916/C47-2016-08

ARIF, M. et al. An architecture of agent-based multi-layer interactive e-learning and e-testing platform. Quality and Quantity, v. 49, n. 6, p. 2435-58, Nov. 2015. https://doi.org/10.1007/s11135-014-0121-9

BADILLA QUINTANA, M. G.; MEZA FERNÁNDEZ, S. A pedagogical model to develop teaching skills. the collaborative learning experience in the Immersive Virtual World TYMMI. Computers in Human Behavior, v. 51, Part B, p. 594-603, Oct. 2015 https://doi.org/10.1016/j.chb.2015.03.016

BETANCOURT, V. La cumbre mundial sobre la sociedad de la información (CMSI). Proceosy temas debatidos, 2004. Obtenido de https://www.apc.org/es/ system/files/wsis_process_ES.pdf

CAMPBELL, T. et al.Technologies and reformed-based science instruction: the examination of a professional development model focused on supporting science teaching and learning with technologies. Journal of Science Education and Technology, v. 24, n. 5, p. 562-79, Oct. 2015. https://doi.org/10.1007/s10956-015-9548-6 
CAMPIÓN, R. S. et al. Las percepciones de los directivos de centros escolares sobre el uso y el valor de las TIC para el cambio e innovación educativa/Perceptions of school leaders about the use and value of ICT for educational change and innovation. Estudios sobre Educación, v. 30, p. 145-74. 2016. https://doi.org.ez.unisabana.edu.co/10.15581/004.30.145-174.

CARNEIRO, R. Motivating school teachers to learn: can ICT add value? European Journal of Education, v. 41, n. 3/4, p. 415-35, 2006.

CHAI, C. S. et al. Modeling primary school pre-service teachers' technological pedagogical content knowledge (TPACK) for meaningful learning with information and communication technology (ICT). Computers and Education, v. 57, n. 1, p. 1184-93, 2011. https://doi.org/10.1016/j.compedu.2011.01.007.

CHEE, Y. S.; MEHROTRA, S. Reflective, reflexive guided appropriation: facilitating teacher adoption of game based learning in classrooms. In: EUROPEAN CONFERENCE ON GAMES BASED LEARNING, 6., 2012, Ireland. [S. n. t.].

CHEN, H.; CHANG, C. Integrating the SOP2 model into the flipped classroom to foster cognitive presence and learning achievements. Journal of Educational Technology \& Society, v. 20, n. 1, p. 274-91, Jan. 2017.

COLL, C. Aprendizaje escolar y construcción del conocimiento. Barcelona: Paidós, 1991.

COUCEIRO, R. M. et al. Design and evaluation of a computer game for the learning of information and communication technologies (ICT) concepts by physical education and sport science students. Education and Information Technologies, v. 18, n. 3, p. 531-54, Sep. 2013. https://doi.org/10.1007/s10639-011-9179-3

DANI, D.; KOENIG, K. Technology and reform-based science education. Theory Into Practice, v. 47, n. 3, 204-11, 2008.

DE, L. V.; KEANE, J.; IRVIN, M. J. Dual perspectives on the contribution of on-site facilitators to teaching presence in a blended learning environment. Journal of Distance Education (Online), v. 25, n. 3, p. 1-14, 2011.

DEANEY, R.; RUTHVEN, K.; HENNESSYY, S. et al. Teachers' developing 'practical theories' of the contribution of information and communication technologies to subject teaching and learning: an analysis of cases from english secondary schools. British Educational Research Journal, v. 32, n. 3, p. 459-80, 2006. 
DEBANDE, O. ICTs and the Development of eLearning in Europe: the role of the public and private sectors. European Journal of Education, v. 39, n. 2, p. 191-208, 2004.

DECLARACION DE INCHEON. Educación 2030. República de Corea, 2015

DREHER, C. et al. Virtual worlds as a context suited for information systems education: Discussion of pedagogical experience and curriculum design with reference to second life. Journal of Information Systems Education, v. 20, n. 2, p. 211-224, 2009.

EBISINE, S. S. Curriculum innovation and information and communication technology (ICT): an analysis. Mediterranean Journal of Social Sciences, v. 6, 4S1, p. 264-7, Nov. 2015. https://doi.org/10.1007/s10639-011-9179-3

EMIN-MARTINEZ, V.; NEY, M. Supporting teachers in the process of adoption of game based learning pedagogy. In: ECGBL 2013 - EUROPEAN CONFERENCE ON GAMES BASED LEARNING, 2013, Porto, Portugal. [S.1..]: ACPI, 2013. p.156-62.

FERNANDES, G.; GONCALVES, P.; AMORIM, A. Gestão de recursos tecnológicos em colégios estaduais baianos: as múltiplas possibilidades de ação pedagógica na EJA. Ensaio: Avaliação e Políticas Públicas em Educação, v. 24, n. 93, p. 890-909, Dec. 2016. https://doi.org/10.1590/S0104-40362016000400006

FRANKLIN, R.; SMITH, J. Practical assessment on the run: iPads as an effective mobile and paperless tool in physical education and teaching. Research in Learning Technology, v. 23, n. 1, p. 279-86, Jan.-Jun. 2015.

GARCÍA-SÁNCHEZ, S.; JOSE, M. Empowering pre-service teachers to produce ubiquitous flipped classes. Profile, v. 19, n. 1, p. 169-85, 2017.

GARCÍA-VALCÁRCEL, A.; BASILOTTA, V.; LÓPEZ, C. ICT in collaborative learningin the classrooms of primary and secondary education. Comunicar, v. 21, n. 42, p. 55-74, 2013.

HAM, S.; CHA, Y. Positioning education in the information society: the transnational diffusion of the information and communication technology curriculum. Comparative Education Review, v. 53, n. 4, p. 535-57, 2009. https://doi.org/10.1086/603584 
HAMILTON, E. R.; ROSENBERG, J. M.; AKCAOGLU, M. The substitution augmentation modification redefinition (SAMR) model: a critical review and suggestions for its use. TechTrends, v. 60, n. 5, p. 433-41, May 2016. https://doi.org/10.1007/s11528-016-0091-y

HERRERA, M.; FERNANDEZ, D.; SEGUEL, R. Percepción de los profesores sobre integración de TIC en las prácticas de enseñanza en relación a los marcos normativos para la profesión docente en Chile. Ensaio: Avaliação e Políticas Públicas em Educação, v. 26, n. 98, p. 163-84, Mar 2018. https://doi.org/10.1590/s0104-40362017002501119.

HOFER, M.; GRANDGENETT, N. TPACK development in teacher education: a longitudinal study of preservice teachers in a secondary M.A.ed. program. Journal of Research on Technology in Education, v. 45, n. 1, p. 83-106, 2012.

HUTCHISON, A.; REINKING, D. Teachers' perceptions of integrating information and communication technologes into literacy instruction: a national survey in the United States. Reading Research Quarterly, v. 46, n. 4, p. 312-33, 2011.

INTERGUAYAMA. Habilidades y competencias del siglo XXI para los aprendices del nuevo milenio en los países de la OCDE. 2010. Available from: $<\mathrm{http}$ ://guayama.inter.edu/wordpress/?wpfb_dl=140>. Access in: 2017 Ago 17.

JIMÉNEZ, A.; ANTONIO, D.; PANTOJA, B. Scaffolding tutoring strategy on virtual environments for training/scaffolding como estrategia de tutoría en entornos virtuales de entrenamiento. Ingeniare : Revista Chilena de Ingenieria, v. 16, n. 2, p. 220-31, 2008.

JIMOYIANNIS, A. esigning and implementing an integrated technological pedagogical science knowledge framework for science teachers professional development. Computers and Education, v. 55, n. 3, p. 1259-69, 2010. https://doi.org/10.1016/j.compedu.2010.05.022.

KABAKCI ,Y. I.; COKLAR, A. N. Modeling preservice teachers' TPACK competencies based on ICT usage. Journal of Computer Assisted Learning, v. 30, n. 4, p. 363-76, Jan. 2014.

KABICHER, S.; DERNTL, M.; MOTSCHNIG-PITRIK, R. ActiveCC: A collaborative framework for supporting the implementation of active curricula. Journal of Educational Multimedia and Hypermedia, 18(4), 429-451.2009. Retrieved from https://search-proquest-com.ez.unisabana.edu.co/docview/193 997865 accountid $=45375$. 
KALE, U.; GOH, D. Teaching style, ICT experience and teachers' attitudes toward teaching with web 2.0. Education and Information Technologies, v. 19, n. 1, p. 41-60, Mar. 2014. https://doi.org /10.1007/s10639-012-9210-3

KARMESHU et al. Modelling diffusion of a personalized learning framework. Educational Technology, Research and Development, v. 60, n. 4, p. 585-600, 2013. https://doi.org.ez.unisabana.edu.co/10.1007/s11423-012-9249-2.

$\mathrm{KOH}, \mathrm{J} . \mathrm{H}$. et al. Understanding the relationship between singapore preservice teachers' ICT course experiences and technological pedagogical content knowledge (TPACK) through ICT course evaluation. Educational Assessment, Evaluation and Accountability, v. 25, n. 4, p. 321-39, 2013. https://doi.org/10.1007/s11092-013-9165-y.

KOH, J. H.; SING, C. C. Modeling pre-service teachers' technological pedagogical content knowledge (TPACK) perceptions: the influence of demographic factors and TPACK constructs. In: ASCILITE 2011, Hobart, Australia. Paper... [S. n. t.]. p. 735-46.

KORANEEKIJ, P.; KHLAISANG, J. Development of learning outcome based e-portfolio model emphasizing on cognitive skills in pedagogical blended e-learning environment for undergraduate students at faculty of education, Chulalongkorn University. Procedia - Social and Behavioral Sciences, v. 174, p. 805-13, Feb. 2015. https://doi.org/10.1016/j.sbspro.2015.01.664

KOSTARIS, C. et al. Investigating the potential of the flipped classroom model in K-12 ICT teaching and learning: An action research study. Educational Technology \& Society, v. 20, n. 1, p. 261-73, Jan. 2017.

KRAUSKOPF, K.; ZAHN, C.; HESSE, F. Leveraging the affordances of Youtube: The role of pedagogical knowledge and mental models of technology functions for lesson planning with technology. Computers and Education, v. 58, n, 4, p. 1194-206, May 2012. https://doi.org/10.1016/j.compedu.2011.12.010

LAGRANGE, J.; ERDOGAN, E. Teachers' emergent goals in spreadsheet-based lessons: analyzing the complexity of technology integration. Educational Studies in Mathematics, v. 71, n. 1, p. 65-84, May 2009. https://doi.org/10.1007/s10649-008-9160-2

LEFEBVRE, S. Intégration des technologies de l'information et de la communication : Types de connaissances abordées dans le discours d'enseignants en exercice et d'étudiants en formation initiale. Canadian Journal of Education, v. 37, n. 3, p. 1-28, 2014. 
LIN, C. A learning ecology perspective: school systems sustaining art teaching with technology. Art Education, v. 64, n. 4 , p. 12-7, 2011.

Application of a model for the integration of technology

in kindergarten: An empirical investigation in taiwan. Early

Childhood Education Journal, v. 40, n. 1, p. 5-17, 2012.

https://doi.org.ez.unisabana.edu.co/10.1007/s10643-011-0494-5

LIU, A.; HODGSON, F.; LORD, W. Innovation in construction education: the role of culture in E-learning. Architectural Engineering and Design Management, v. 6, n. 2, p. 91-102, 2010.

LIU, X. et al. Teachers' use of PowerPoint in kindergarten: an empirical investigation in China. Education and Information Technologies, v. 1, n. 2, p. 425-41, Mar. 2016. https://doi.org/10.1007/s10639-014-9330-z

LOCKLEY, A.; BOYLE, A. Towards a game-based learning ecosystem: An institutional strategy. In: EUROPEAN CONFERENCE ON GAMES-BASED LEARNING, 8., 2014, Berlin. Proceedings... [S. n. t. ]. p. 312-20.

MANESSIS, D. Examining early childhood education students' attitudes toward educational computer games in kindergarten. In: ECGBL 2013 EUROPEAN CONFERENCE ON GAMES BASED LEARNING, 2013, Porto, Portugal. [S. 1.]: ACPI, 2013. p. 369-77.

MARCOUX, E.; LOERTSCHER, D. V. Achieving teaching and learning excellence with technology. Teacher Librarian, v. 37, n. 2, p. 14-22,88, 2009.

MARTÍN, A. H.; DE ARRIBA, J. M. Concepciones de los docentes no universitarios sobre el aprendizaje colaborativo con TIC/ (concepts of non-university teachers on collaborative learning with ICT). Educación XX1, v. 20, n. 1, p. 185-208, 2017. https://doi.org.ez.unisabana.edu.co/10.5944/educXX1.1286

McINERNEY, C. R. Educational inquiry and creativity: developing digital resources in ireland's information age town. Library Trends, v. 54, n, 2, p. 266-85, 2005.

MISHRA, P.; KOEHLER, M. J. Technological pedagogical content knowledge: a new framework for teacher knowledge. Teachers College Record, v. 108, n. 6, p. 1017-54, 2006. 
MURTHY, S.; IYER, S.; WARRIEM, J. ET4ET: a large-scale faculty professional development program on effective integration of educational technology. Educational Technology and Society, v. 18, n. 3, p. 16-2, 2015.

NIEMEL, P. S.; HELEVIRTA, M. K-12 curriculum research: The chicken and the egg of math-aided ICT teaching. International Journal of Modern Education and Computer Science, v. 9, n. 1, 1-14, 2017. https://doi.org/10.5815/ijmecs.2017.01.01

NKONKI, V.; NTLABATHI, S. Teaching and learning innovations on blackboard: What form and function?

In: INTERNATIONAL CONFERENCE ON E-LEARNING, 11. , 2016, Kuala Lampur, Malysia. Proceedings... [S. n. t.]. p. 120-6.

NYAGOWA, H. O. The influence of infrastructure, training, content and communication on the success of NEPAD'S pilot e-schools in kenya. Information Development, v. 30, n. 3, p. 235-46, 2014. https://doi.org/10.1177/0266666913489698

OKOLI, C.; SCHABRAM, K. A guide to conducting a systematic literature. Sprouts, v. 10, n. 26, p. 1-51, 2010.

ONWUAGBOKE, B. B.; SINGH, T. K.; FOOK, F. S. Integrating technology in art education in nigerian education system: the need for an effective pedagogical approach. Mediterranean Journal of Social Sciences, v. 6, n. 4, p. 184-92, 2015. https://doi.org/10.5901/mjss.2015.v6n4s1p184

PEARSON, M. Modeling universal design for learning techniques to support multicultural education for pre-service secondary educators. Multicultural Education, v. 22, n. 3, p. 27-34, 2015.

PEINADO-MIGUEL, F. et al. Learning and innovation: a methodological proposal from the teaching of media management. Revista Latina de Comunicación Social, n. 68, p. 115-38, 2013. https://doi.org/10.4185/RLCS-2013-971en

PETKO, D. Teachers' pedagogical beliefs and their use of digital media in classrooms: sharpening the focus of the "will, skill, tool" model and integrating teachers' constructivist orientations. Computers and Education, v. 58, n. 4, p. 1351-9, 2012. https://doi.org/10.1016/j.compedu.2011.12.013 
POHL, M. et al.. Computer supported collaborative learning and vocational training: Adapting the technology to the learners' needs. Universal Access in the Information Society, v. 7, n. 4, p. 259-72, 2008. https://doi.org.ez.unisabana.edu.co/10.1007/s10209-008-0119-y

RAJU, S. V. et al. Role of ICT in outcome based education. In: INTERNATIONAL ADVANCED COMPUTING CONFERENCE IACC2016, 6., 2016, Bhimavaram, India. Proceedings... [S. n. t.]. p. 815-9.

RANIERI, M. et al. Mobile learning for the integration of groups that risk being marginalized. Journal of E-Learning and Knowledge Society, v. 5, n. 2, p. 75-85, 2009.

RENDA, G.; KUYS, B. Connectivism as a pedagogical model within industrial design education. Procedia Technology, v. 20, p. 15-9, 2015. https://doi.org/10.1016/j.protcy.2015.07.004

ROMERO-MARTÍN, R. et al. Evaluación formativa, competencias comunicativas y TIC en la formación del profesorado. Comunicar, v. 25, n. 52, p. 73-82, 2017. https://doi.org/10.3916/C52-2017-07

RUTHVEN, K.; DEAMEU, R.; HENNESSY, S. Graphing software to teach about algebraic forms: a study of technology-supported practice in secondary-school mathematics. Educational Studies in Mathematics, v. 71, n. 3, p. 279-97, 2009.

RUTHVEN, K.; HENNESSY, S. A practitioner model of the use of computer-based tools and resources to support mathematics teaching and learning. Educational Studies in Mathematics, v. 49, n. 1, p. 47-88, 2002.

SAMPAIO, P. A. S. R. Conhecimento tecnológico dos professores de Matemática sobre quadros interativos segundo as políticas públicas de formação contínua. Ensaio: Avaliação e Políticas Públicas em Educação, v. 24, n. 93, p. 845-65, Dec. 2016. https://doi.org/10.1590/S0104-40362016000400004

SANGRA, A.; GONZALEZ-SANMAMED, M. The role of information and communication technologies in improving teaching and learning processes in primary and secondary schools. ALT-J: Research in Learning Technology, v. 18 , n. 3, p. 207-20, 2010. https://doi.org/10.1080/09687769.2010.529108

SAXENA, A. Issues and impediments faced by canadian teachers while integrating ICT in pedagogical practice. Turkish Online Journal of Educational Technology, v. 16, n. 2, p. 58-70, Apr. 2017. 
SEGREDO, E.; MIRANDA, G.; LEÓN, C. Hacia la educación del futuro: el pensamiento computacional como mecanismo de aprendizaje generativo. Education in the Knowledge Society, v. 18, n. 2, p. 33-58, 2017. https://doi.org/10.14201/eks20171823358

SHARIJA, M. A.; WATTERS, J. J. Innovative leadership by school principals: embedding information communication and technology in kuwaiti schools. Journal of International Education, v. 8, n. 4, p. 425-34, 2012.

SILVA, J. B. et al. Adaptation model of mobile remote experimentation for elementary schools. Revista Iberoamericana de Tecnologias Del Aprendizaje, v. 9, n. 1, p. 28-32, 2014. https://doi.org/ 10.1109/RITA.2014.2302053

SLOEP, P. B. et al.. Innovating education with an educational modelling language: Two case studies. Innovations in Education and Teaching International, v. 43, n. 3, p. 291-302, 2006.

SMITH, H. et al. Classroom e-science: exposing the work to make it work. Journal of Educational Technology \& Society, v. 12, n. 3, p. 289-308, 2009.

SUÁREZ-GUERRERO, C.; LLORET-CATALÁ, C.; MENGUAL ANDRÉS, $\mathrm{S}$. Teachers' perceptions of the digital transformation of the classroom through the use of tablets: a study in Spain/Percepción docente sobre la transformación digital del aula a través de tabletas: un estudio en el contexto español. Comunicar, v. 24, n. 49, p. 81-9, 2016.

TAI, H et al. Applying Technological Pedagogical and Content Knowledge (TPACK) model to develop an online English writing course for nursing students. Nurse Education Today, v. 35, n. 6, p. 782-8, 2015. https://doi.org/10.1016/j.nedt.2015.02.016

TALLVID, M. Understanding teachers' reluctance to the pedagogical use of ICT in the 1:1 classroom. Education and Information Technologies, v. 21, n. 3, p. 503-19, 2016. https://doi.org/10.1007/s10639-014-9335-7

TAPISKA, S.et al. What deters primary school teachers from using ICT? In: INTERNATIONAL SYMPOSIUM ON INTELLIGENT SYSTEMS AND INFORMATICS - SISY 2016, 14., 2016, Subotica, Serbia. Proceedings... [S. n. t.]. p. 193-8.

TAYLOR, J.; DURAN, M. Teaching social studies with technology: new research on collaborative approaches. The History Teacher, v. 40, n. 1, p. 9-25. 2006. https://doi.org/10.2307/30036936. 
THUNE, T.; WELLE-STRAND, A. ICT for and in Internationalization Processes: A Business School Case Study. Higher Education, v. 50, n. 4, p. 593-611, 2005.

TOH, Y. Leading sustainable pedagogical reform with technology for student-centred learning: a complexity perspective.

Journal of Educational Change, v. 17, n. 2, p. 145-69, 2016.

https://doi.org/10.1007/s10833-016-9273-9

UIT - UNIÓN INTERNACIONAL DE TELECOMUNICACIONES. Cumbre mundial sobre la sociedad de la información, 2003, Ginebra. Documentos finales. Ginebra, 2005. Available from: $<$ https://www.itu.int/net/wsis/outcome/ booklet-es.pdf>. Access in: 2017 Ago 17.

URSAVAS, Ö. F. The influence of hedonic and utilitarian motivations on teachers behavioral intention to use tablet PCs. Egitim Ve Bilim, v. 40, n. 179, p. 25-43, 2015. https://doi.org/10.15390/EB.2015.4346

VAN LAER, S.; BEAUCHAMP, G.; COLPAERT, J. Teacher use of the interactive whiteboards in flemish secondary education--mapping against a transition framework. Education and Information Technologies, v. 19, n. 2, p. 409-23, 2014. https://doi.org/10.1007/s10639-012-9228-6

VANDERLINDE, R.; JOHAN, V. B. A new ICT curriculum for primary education in flanders: Defining and predicting teachers' perceptions of innovation attributes. Journal of Educational Technology \& Society, v. 14, n. 2, p. 124-35, 2011.

VERA VÉLEZ, L. La rúbrica y la lista de cotejo. Puerto Rico: Universidad Interamericana de Puerto Rico, 2008.

VIRKUS, S. Use of web 2.0 technologies in LIS education: Experiences at tallinn university, estonia. Program, v. 42, n. 3, p. 262-274,. 2008. https://doi.org/10.1108/00330330810892677

WANG, Q. A generic model for guiding the integration of ICT into teaching and learning. Innovations in Education and Teaching International, v. 45, n. 4, p. 411-9, 2008.

WARRIEM, J. M.; MURTHY, S.; IYER, S. A2I: A model for teacher training in constructive alignment for use of ICT in engineering education. In: INTERNATIONAL CONFERENCE ON COMPUTERS IN EDUCATION ICCE 2014, 22., Nara, Japan. Proceedings... [S. n. t. ]. p. 896-902, 2014. 
WEBB, S. Can ICT reduce social exclusion? The case of an adults' English Language Learning Programme. British Educational Research Journal, v. 32, n. 3, p. 481-507, 2006.

WILLIAMS, L. et al. Mutual support between learning community development and technology integration: impact on school practices and student achievement. Theory Into Practice, v. 47, n. 4, p. 294-302, 2008. https://doi.org/10.1080/00405840802329219

YILDIZ, B.; KOÇAK, Y. A model proposal on ICT integration for effective mathematics instruction. Hacettepe Egitim Dergisi, v. 31, n. 1, p. 14-33 Jan. 2016. https://doi.org/10.16986/HUJE.2015013971

YUNUS, M. Malaysian ESL teachers' use of ICT in their classrooms: Expectations and realities. ReCALL. The Journal of EUROCALL, v. 19, n. 1, p. 79-95, 2007.

ZAGAMI, J. Social ecological model analysis for ict integration. Australian Educational Computing, v. 27, n. 3, p. 143-49, 2013. https://doi.org/10.16986/HUJE.2015013971

ZHU, C. How innovative are schools in teaching and learning? A case study in beijing and hong kong. The Asia - Pacific Education Researcher, v. 22, n. 2, p. 137-45, 2013. https://doi.org.ez.unisabana.edu.co/10.1007/s40299-012-0006-4

ZYAD, H. Integrating computers in the classroom: Barriers and teachers' attitudes. International Journal of Instruction, v. 9, n. 1, p. 65-78, Jan. 2016. https://doi.org/10.12973/iji.2016.916a

\section{Informações das autoras}

Olga González Sosa: Professora do Centro de Tecnologías para la academia da Universidad de La Sabana. Contato: olgagonso@unisabana.edu.co

Cristina Hennig Manzuoli: Professora do Centro de Tecnologías para la academia da Universidad de La Sabana. Contato: cristinahm@unisabana.edu.co 